\title{
KORELASI TINGKAT KEBERMAKNAAN HIDUP DENGAN DEPRESI PADA LANSIA DI POSYANDU LANSIA PADUKUHAN SOROPADAN, SLEMAN, YOGYAKARTA
}

\author{
Jimmi MP Aritonang, Soewadi, Ronny Tri Wirasto \\ Bagian Kedokteran Jiwa Fakultas Kedokteran Universitas Gadjah Mada
}

Korespondensi: jimmi.m.p.aritonang@mail.ugm.ac.id

\begin{abstract}
ABSTRAK
Latar Belakang: Kekurangan kebermaknaan hidup bisa menjadi sebab maupun akibat kondisi depresi, baik kekurangan makna maupun kondisi depresi bisa ditimbulkan oleh penyebab-penyebab lainnya. Mengenali depresi pada lanjut usia memerlukan suatu keterampilan dan pengalaman, karena manifestasi gejalagejala depresi klasik sering tidak muncul.

Tujuan: Untuk mengetahui korelasi antara tingkat kebermaknaan hidup dengan depresi pada lansia di Posyandu Lansia Padukuhan Soropadan, Sleman, Yogyakarta.

Metode: Penelitian non eksperimental dengan rancangan cross-sectional, subjek penelitian adalah lansia di Posyandu Lansia Padukuhan Soropadan dengan menggunakan instrumen Meaning In Life Questionnaire (MLQ) versi Indonesia; tingkat depresi dinilai dengan menggunakan instrumen Geriatric Depression Scale (GDS-15) versi Indonesia. Analisis data univariat untuk mengetahui profil subjek penelitian, analisis bivariat untuk mengetahui kekuatan korelasi tingkat kebermaknaan hidup dan tingkat depresi pada lansia dianalisis dengan uji koefisien korelasi phi dan analisis multivariat untuk mengetahui kekuatan pengaruh dari faktor-faktor perancu dengan uji analisis multipel regresi.

Hasil Penelitian: Terdapat korelasi yang bermakna antara tingkat kebermaknaan hidup dengan depresi pada lansia $(r=-0,331, p=0,007)$ di posyandu lansia Padukuhan Soropadan dengan kekuatan korelasi yang cukup.

Kesimpulan: Terdapat korelasi yang bermakna antara tingkat kebermaknaan hidup dengan depresi pada lansia di Posyandu Lansia Padukuhan Soropadan.
\end{abstract}

Kata Kunci: kebermaknaan hidup-depresi-lansia, posyandu lansia Yogyakarta. 


\title{
CORRELATION OF LIVELIHOOD LEVEL WITH DEPRESSION ON ELDERLY AT POSYANDU LANSIA SOROPADAN, SLEMAN, YOGYAKARTA
}

\author{
Jimmi MP Aritonang, Soewadi, Ronny Tri Wirasto \\ Departement of Psychiatric Medical Faculty, Universitas Gadjah Mada
}

Correspondence: jimmi.m.p.aritonang@mail.ugm.ac.id

\begin{abstract}
ABSTRCT
Background: Lack of meaningfulness of life can be a cause or effect of depression conditions, both lack of meaning and conditions of depression can be caused by other causes. Recognizing depression in the elderly requires a skill and experience, because the manifestations of classic depressive symptoms often do not appear.

Objective: To know the correlation between the level of meaningfulness of life with depression in elderly in Posyandu Elderly Padukuhan Soropadan, Sleman, Yogyakarta.

Method: Non experimental study with cross-sectional design, research subjects were elderly at Elderly Posy Padukuhan Soropadan using the Indonesian version of Meaning In Life Questionnaire; depression rates were assessed using the Indonesian version of the Geriatric Depression Scale instrument. Analysis of univariate data to know the profile of research subject, bivariate analysis to know correlation strength of life meaning level and depression level in elderly analyzed with phi coefficient correlation test and multivariate analysis to know strength influence from confounding factor with multiple regression analysis test.

Results: There is a significant correlation between the level of meaningfulness of life with depression in the elderly $(r=-0.331, p=0.007)$ in posyandu elder Padukuhan Soropadan with enough correlation strength.

Conclusion: There is a significant correlation between the level of meaningfulness of life with depression in elderly in Posyandu Elderly Padukuhan Soropadan.
\end{abstract}

Keywords: meaningfulness of life-depression-elderly, posyandu elderly Yogyakarta. 


\section{LATAR BELAKANG MASALAH}

Hasil proyeksi penduduk 2010-2035, Indonesia akan memasuki periode lansia (ageing), dimana $10 \%$ penduduk akan berusia 60 tahun ke atas di tahun 2020.1 Berdasarkan data CIA World Factbook, (2016) Indonesia merupakan negara ke-empat dunia dengan jumlah penduduk terbanyak setelah China, India, Amerika Serikat. ${ }^{2}$ Menurut United Nations, pada tahun 2013 populasi penduduk lansia Indonesia yang berumur 60 tahun atau lebih berada pada urutan 108 dari seluruh negara di dunia. Memang pada saat itu, populasi lansia di Indonesia masih dikategorikan belum terlalu besar. Namun diprediksikan pula bahwa di tahun 2050, Indonesia akan masuk menjadi sepuluh besar negara dengan jumlah lansia terbesar, yaitu berkisar 10 juta lansia. ${ }^{3}$

Daerah Istimewa Yogyakarta (DIY) merupakan propinsi yang paling diwaspadai, karena mempunyai Angka Harapan Hidup (AHH) lansia tertinggi se-Indonesia yaitu sebesar 73,27 dimana $\mathrm{AHH}$ secara Nasional sebesar 69,65 (Dinas Kesehatan DIY, 2013) dan jumlah lansia tertinggi di Indonesia dengan menyumbang sebesar 13,4\%. ${ }^{1}$ Berdasarkan data Dinas Kesehatan DIY tahun 2013 Kabupaten Sleman merupakan daerah yang mempunyai AHH yang tertinggi di DIY yaitu sebesar 75,18 .

Proses menua merupakan proses yang terus menerus atau berkelanjutan secara alamiah dan umumnya dialami oleh semua makhluk hidup. Secara fisik, lansia mengalami perubahan organobiologik, degenerasi/ penuaan organ tubuh, kapasitas dan fungsi-fungsi organ tubuh menurun.

Secara mental, lansia sering mengalami gangguan mental antara lain: insomnia, stress psikososial, anxiety, depresi, gangguan perilaku: agresif, agitasi. ${ }^{4}$ World Health Organization (WHO) memperkirakan bahwa pada tahun 2020 depresi akan naik dari urutan keempat menjadi urutan kedua di bawah penyakit jantung iskemik sebagai penyebab disabilitas dan beban kesehatan serta menjadi urutan pertama pada tahun 2030.5

Prevalensi depresi pada lansia di dunia sekitar 8-15\%. Pada penelitian di Kota Yogyakarta didapatkan prevalensi depresi pada lansia sebesar $46,1 \%$, dimana pada pria dengan depresi mencapai $23,7 \%$ dan wanita dengan depresi ditemukan sebanyak 76,3\%.6

Gangguan depresi pada lanjut usia merupakan perhatian yang paling penting bagi para ahli geriatri. Mengenali depresi pada lanjut usia memerlukan suatu keterampilan dan pengalaman, karena manifestasi gejala-gejala depresi klasik sering tidak muncul.

Kehilangan kebermaknaan hidup dapat menurunkan semangat hidup, yang pada gilirannya dapat menyebabkan perasaan kekosongan dan depresi, dan dalam kasus terburuk hingga bunuh diri. ${ }^{7}$ Penelitian Harvina (2014) dan Kállay (2015), menunjukkan bahwa manusia yang tidak mempunyai maupun yang rendah taraf kebermaknaan hidup memiliki tingkat depresi yang lebih tinggi dibandingkan dengan yang mempunyai kebermaknaan dalam hidupnya. 8,9 Posyandu Lansia Padukuhan Soropadan merupakan salah satu posyandu lansia yang berada dalam wilayah Desa Condong Catur, Kecamatan Depok, Kabupaten Sleman, DIY. Posyandu ini berdiri sejak Januari 2013 dibawah pimpinan ibu Ketua PKK Padukuhan Soropadan. Posyandu Lansia Padukuhan Soropadan aktif melakukan kegiatan setiap bulannya dan setiap hari Senin rutin 
mengadakan kegiatan senam lansia, dan bekerjasama dengan Klinik Gereja GKI Gejayan dalam hal pemeriksaan oleh dokter umum.

Saat ini Posyandu Lansia Padukuhan Soropadan, Sleman, Yogyakarta memiliki 10 orang kader dan salah satunya adalah seorang kader jiwa yang sudah pernah mendapatkan pelatihan dari puskesmas, tetapi kader jiwa yang ada belum pernah melakukan kegiatan yang menyangkut kesehatan mental.

Berdasarkan permasalahan yang berhubungan dengan kesehatan mental tersebut perlu dilakukannya penelitian terkait depresi dan kebermaknaan hidup pada lansia yang ada di Posyandu Lansia Soropadan. Atas dasar itulah peneliti tertarik untuk melakukan penelitian tentang "Korelasi tingkat kebermaknaan hidup dengan depresi pada lansia di Posyandu lansia Padukuhan Soropadan, Sleman, D.I.Yogyakarta".

\section{METODE PENELITIAN}

\section{Jenis dan Rancangan Penelitian}

Penelitian ini merupakan penelitian non eksperimental dengan rancangan cross sectional, bersifat deskriptif korelatif. Rancangan ini bertujuan untuk mengetahui korelasi antara tingkat kebermakna-an hidup dengan depresi pada lansia di Posyandu Lansia Padukuhan Soropadan, Sleman, Yogyakarta.

\section{Tempat dan Waktu Penelitian}

Penelitian ini dilaksanakan di Posyandu Lansia Padukuhan Soropadan, Sleman, Yogyakarta, selama empat minggu di bulan Juni 2017.

\section{Subjek Penelitian}

1. Populasi Penelitian

Populasi penelitian ini adalah lansia yang ada di Posyandu Lansia Padukuhan Soropadan, Sleman, Yogyakarta. Adapun yang menjadi subjek penelitian ini adalah responden yang memenuhi kriteria inklusi dan ekslusi.

Kriteria inklusi sebagai berikut (a) Berusia $\geq 60$ tahun dan tinggal di padukuhan Soropadan, (b) Pendidikan minimal lulus SD (bisa baca tulis), (c) bersedia menanda-tangani persetujuan menjadi responden penelitian.

Kriteria ekslusi: (a) Tidak menyelesaikan pengisian instrumen dengan lengkap.

2. Besar sampel

Penelitian ini merupakan penelitian analitik korelatif. Maka besar sampel penelitian ini sebanyak 50 sampel. ${ }^{10}$

3. Cara pengambilan sampel

Pengambilan sampel pada penelitian ini dengan menggunakan teknik pengambil-an sampel non probabilistik dengan cara purposive sampling, yaitu tehnik pengambilan sampel dengan cara mengambil sampel sesuai dengan kriteria yang sudah ditetapkan sampai jumlah sampel memenuhi. 11

\section{Identifikasi Variabel Penelitian}

Variabel-variabel pada penelitian ini adalah (1) Variabel bebas: kebermaknaan hidup, (2) Variabel tergantung: depresi, (3) Variabel pengganggu: Usia, Jenis kelamin, Riwayat Pendidikan, Pekerjaan dan Status Pernikahan.

\section{Definisi Operasional Variabel}

(1) Kebermaknaan hidup: Suatu keadaan yang membuat individu merasakan hidupnya lebih bahagia, lebih berharga, dan memiliki tujuan hidup yang jelas untuk dipenuhinya. Aspek kebermaknaan hidup dilihat dari dua sisi yaitu sisi presence of meaning in life dan search for meaning in life. Kebermaknaan hidup dinyatakan dengan skor kebermaknaan hidup, diukur dengan instrumen Meaning in Life 
Questionnare (MLQ) versi Indonesia. Untuk analisis data dalam tabel kontingensi $2 \times 2$, skor penilaian dari subjek penelitian akan dikelompokkan menjadi dua kelompok yaitu kebermaknaan hidup rendah dengan skor 10-27 dan kebermaknaan hidup tinggi dengan skor 28-40. Skala pengukuran yang digunakan adalah skala kategorik (nominal). (2) Depresi: Gejala depresi yang dinyatakan dengan skor depresi, diukur menggunakan instrumen Geriatric Depression Scale-15 (GDS-15) versi Indonesia. Untuk analisis data dalam tabel kontingensi $2 \times 2$, skor depresi dari subjek penelitian dikelompokkan menjadi dua kelompok yaitu tidak depresi dengan skor 0-4 dan depresi dengan skor 5-15. Skala pengukuran yang digunakan adalah skala kategorik (nominal).

\section{Instrumen Penelitian}

Meaning in Life Questionnaire (MLQ) versi Indonesia

Instrumen yang digunakan untuk menilai makna hidup dalam penelitian ini adalah : Meaning in Life Questionnaire (MLQ) dari Steger et al, (2006) versi Indonesia. Kuesioner terdiri dari 10 item pernyataan yang terdiri dari dua subskala yaitu kondisi makna hidup saat ini (Presence of Meaning/POM) dan pencarian makna hidup (Search for Meaning/SFM). ${ }^{12}$ Instrumen ini memiliki skala likert yang dimulai dari nilai 1-4 dengan total nilai yang akan dihasilkan berkisar dari 10-40. Skor yang dihasilkan menggambarkan kemampuan subjek dalam memaknai hidupnya, semakin tinggi skor yang dihasilkan subjek berarti semakin tinggi kemampuan subjek memaknai hidup. ${ }^{13}$

Instrumen Meaning in Life Questionnaire versi Indonesia ini sudah divalidasi oleh Nauli, 2011 dan Alim, 2012. Tingkat keakuratan dari instrumen ini terdiri atas hubungan negatif $(\mathrm{r}=-0.09, \mathrm{p}>0.05)$, konsistensi internal reliability dari item kondisi makna hidup yang telah dicapai (presence) terhadap ujicoba kuesioner pada 3 (tiga) penelitian yang dilakukan yaitu dengan koefisien $0.86,0.86,0.82$, sedangkan untuk item pertanyaan tentang pengkajian terhadap pencarian makna hidup (search) dengan koefisien 0.87, 0.86, dan 0.87. Ini menunjukkan tingkat validitas dari masing-masing skala pengkajian tersebut. 14

Skala makna hidup ini telah tervalidasi dengan baik ke dalam bahasa Indonesia oleh peneliti sebelumnya dimana hasil uji validitas pada sepuluh item didapatkan valid $(\mathrm{p}<0.05, \mathrm{r}=0,63-0,77)$ dan hasil uji reliabilitas Cronbach Alpha didapatkan nilai dimensi presence of meaning in life 0,82 dan nilai dimensi search for meaning in life 0,87 (alat ukur dikatakan reliabel apabila nilai Cronbach Alpha lebih besar dari 0,70). ${ }^{13,15,16}$

Peringkat ini menghasilkan skor 10-40. Adapun kategori variabel kebermaknaan hidup dapat dilihat pada tabel 1.13

Tabel 1. Kategori Variabel Kebermaknaan Hidup

\begin{tabular}{ccc}
\hline Variabel & Kategori & Skor \\
\hline \multirow{3}{*}{ Makna Hidup } & Tinggi & $36-40$ \\
& Sedang & $28-35$ \\
& Rendah & $10-27$ \\
\hline
\end{tabular}

Kelebihan instrumen MLQ dibandingkan instrumen lain yang 
sejenis, adalah telah terbukti akurat mengukur makna hidup pada subjek depresi. ${ }^{15}$

Geriatric Depression Scale-15 (GDS15) versi Indonesia

\section{Geriatric Depression Scale} (GDS) merupakan skala penilaian depresi pada lanjut usia yang diciptakan oleh Yesavage \& Brink (1983) dalam Bahasa Inggris. Dalam penelitian yang dilakukan oleh Jeon et al (2014) tentang validitas kuesioner Geriatric Depression Scale didapatkan hasil kuesioner GDS memiliki tingkat sensitifitas 92\% dan spesifisitas 89\%. Geriatric Depression Scale-15 (GDS-15) memiliki format yang sederhana, dengan pertanyaanpertanyaan dan respon yang mudah dibaca. GDS-15 telah divalidasi pada berbagai populasi lanjut usia termasuk di Indonesia.

\section{Prosedur Pengambilan dan Pengumpulan Data}

Data primer diperoleh berdasarkan pengisian kuesioner isian data dasar yang berisi data demografik, karakteristik subjek penelitian, serta berdasarkan pengisian instrumen Meaning in Life Questionnare (MLQ) versi Indonesia dan Geriatric Depression Scale-15 (GDS-15I) versi Indonesia terhadap lansia yang ada di posyandu lansia padukuhan Soropadan, Sleman, Yogyakarta. Prosedur pengambilan data dilakukan dengan cara: setiap lansia yang ditemui, dimintai kesediaanya mengikuti penelitian. Apabila mereka setuju, dilanjutkan dengan proses pengambilan data primer sampai dengan selesai. Data sekunder diperoleh dari kepustakaan, ketua dan kader posyandu lansia padukuhan Soropadan, Sleman, Yogyakarta.

\section{Cara Analisis Data}

Pada penelitian ini data yang diperoleh akan dianalisis dengan menggunakan program Statistical Package for Social Science (SPSS) IBM versi 24. Analisis yang dilakukan adalah analisis univariat, bivariat, dan multivariat terhadap variabelvariabel penelitian yang telah ditetapkan.

Analisis univariat dilakukan dengan cara variabel-variabel yang ada dalam penelitian ini disusun secara deskriptif melalui tabel frekuensi. Analisis bivariat dilakukan untuk mengetahui korelasi kebermaknaan hidup dengan depresi. Data kebermaknaan hidup berupa skala kategorik nominal dan skor depresi berupa skala kategorik nominal yang akan dianalisis dengan uji chi-square, bila nilai yang diharapkan $<5$ akan digunakan uji Mantel Haenszel. Dan untuk mengetahui kekuatan korelasi kebermaknaan hidup dan depresi pada lansia akan dianalisis dengan uji koefisien korelasi phi. ${ }^{17}$ Analisis multivariat dilakukan untuk mengetahui faktor yang paling berpengaruh terhadap variabel depresi, dengan menggunakan analisis multivariat regresi logistik. ${ }^{18}$

\section{Etika Penelitian}

Penelitian ini dilaksanakan dengan mengajukan ethical clearance ke Komite Etik Penelitian Kedokteran dan Kesehatan Fakultas Kedokteran Universitas Gadjah Mada (Medical and Health Research Ethics Committee (MHREC) Faculty of Medicine Universitas Gadjah Mada). Informed consent dilakukan pada penelitian ini bertujuan untuk memberikan informasi kepada subjek penelitian serta meminta persetuju-an untuk ikut serta dalam penelitian ini.

\section{HASIL DAN PEMBAHASAN}

\section{Deskripsi Subjek Penelitian}

Penelitian dilakukan di

Posyandu Lansia Padukuhan Soropadan, Sleman, Yogyakarta pada bulan Juni 2017. Data-data penelitian disajikan dalam bentuk tabel dan narasi. Pada penelitian ini 
diambil sampel sebanyak 105 subjek. Total subjek penelitian adalah 103 orang, sedang 2 subjek lainnya masuk kriteria eksklusi dengan alasan yaitu: 1 orang dengan retardasi mental dan 1 orang tidak mengisi kuesioner dengan lengkap Gambaran karakteristik subjek penelitian dapat dilihat pada
Tabel 2. Jenis kelamin subyek penelitian terdiri dari laki-laki 33 orang (32\%) dan perempuan 70 orang $(68 \%)$. Subjek penelitian yang berusia 60-70 tahun sebanyak 98 orang $(95 \%)$ dan di atas 70 tahun sebanyak 5 orang $(5 \%)$.

Tabel 2. Frekuensi Distribusi Karakteristik Subjek Penelitian

\begin{tabular}{llcc}
\hline & Variabel & N & \% \\
\hline \multirow{2}{*}{ Jenis Kelamin } & Perempuan & 70 & 68 \\
\multirow{2}{*}{ Umur } & Laki-laki & 33 & 32 \\
\multirow{2}{*}{ Pernikahan } & $>70$ tahun & 5 & 5 \\
& 60-70 tahun & 98 & 95 \\
Pekerjaan & Tidak menikah & 26 & 25 \\
\multirow{2}{*}{ Tingkat Pendidikan } & Menikah & 77 & 75 \\
\multirow{2}{*}{ Depresi } & Tidak Bekerja & 49 & 48 \\
\multirow{2}{*}{ Tingkat Kebermaknaan Hidup } & Bekerja & 54 & 52 \\
& Rendah & 30 & 29 \\
& Tinggi & 73 & 71 \\
& Depresi & 30 & 29 \\
& Tidak Depresi & 73 & 71 \\
& Rendah & 6 & 6 \\
& Tinggi & 97 & 94 \\
\hline
\end{tabular}

Status pernikahan subjek penelitian 77 orang $(75 \%)$ menikah sedangkan 26 orang (25\%) tidak menikah, janda atau duda. Subjek penelitian sebagian besar berpendidikan tinggi sebanyak 73 orang $(71 \%)$ dan yang berpendidikan rendah 30 orang (29\%). Depresi ditemukan pada 30 orang (29\%) subjek penelitian, dimana paling banyak pada wanita sebanyak 18 orang $(17 \%)$ dan laki-laki 12 orang $(12 \%)$. Sebanyak 6 orang $(6 \%)$ subjek penelitian tingkat kebermaknaan hidupnya rendah dan 97 orang (94\%) tingkat kebermaknaan hidupnya tinggi.

\section{Analisis Bivariat Korelasi antara Tingkat Kebermaknaan Hidup dengan Depresi}

Dari data yang terkumpul, kemudian dilakukan analisa bivariat dengan menggunakan uji Mantel Haenszel dan Korelasi Phi antara tingkat kebermaknaan hidup dengan dengan depresi. Hasil uji Bivariat tersebut dapat dilihat dalam Tabel 3. 
Tabel 3. Analisis Bivariat antara variabel Tingkat Kebermaknaan Hidup dengan Depresi pada Subjek Penelitian.

\begin{tabular}{|c|c|c|c|c|c|c|}
\hline \multirow{2}{*}{$\begin{array}{l}\text { Ke- } \\
\text { bermakna- } \\
\text { an Hidup }\end{array}$} & \multicolumn{2}{|c|}{$\mathbf{Y a}$} & \multicolumn{2}{|c|}{ Tidak } & \multicolumn{2}{|c|}{$\sum$} \\
\hline & $\mathbf{f}$ & $\%$ & $\mathbf{f}$ & $\%$ & $\mathbf{f}$ & $\%$ \\
\hline Rendah & 5 & 5 & 1 & 1 & 6 & 6 \\
\hline Tinggi & 25 & 24 & 72 & 70 & 97 & 94 \\
\hline$\sum$ & 30 & 29 & 73 & 71 & 103 & 100 \\
\hline
\end{tabular}

Dari semua subjek penelitian yang menderita depresi, sebanyak 5 orang $(5 \%)$ tingkat kebermaknaan hidup rendah dan 25 orang (24\%) tingkat kebermaknaan hidup tinggi. Sedangkan dari semua subjek penelitian yang tidak depresi, yang tingkat kebermaknaan hidup rendah ada 1 orang $(1 \%)$ dan 72 orang $(70 \%)$ tingkat kebermaknaan hidup tinggi. Dari hasil analisis nilai $\mathrm{p}$ sebesar $0,007 \quad\left(\mathrm{X}^{2} \mathrm{MH}=8,98 ; \quad \mathrm{p}<0,05, \quad \mathrm{df}=1\right)$, yang artinya secara statistik terdapat korelasi yang bermakna antara tingkat kebermaknaan hidup dengan depresi. Nilai koefisien korelasi phi didapatkan $r=-0,3$, yang artinya kekuatan korelasinya cukup antara tingkat kebermaknaan hidup dengan depresi, dimana arah korelasi bersifat negatif, artinya semakin tinggi tingkat kebermaknaan hidup maka semakin tidak ditemukan adanya depresi.

\section{Analisis Bivariat antara Variabel Lain dengan Depresi}

Analisis Bivariat antara variabel lain dengan depresi pada lansia di Posyandu Lansia Padukuhan Soropadan, Sleman, Yogyakarta, pada bulan Juni 2017 dapat di lihat pada Tabel 4.

Tabel 4. Analisis Bivariat antara Variabel Pengganggu dengan Depresi

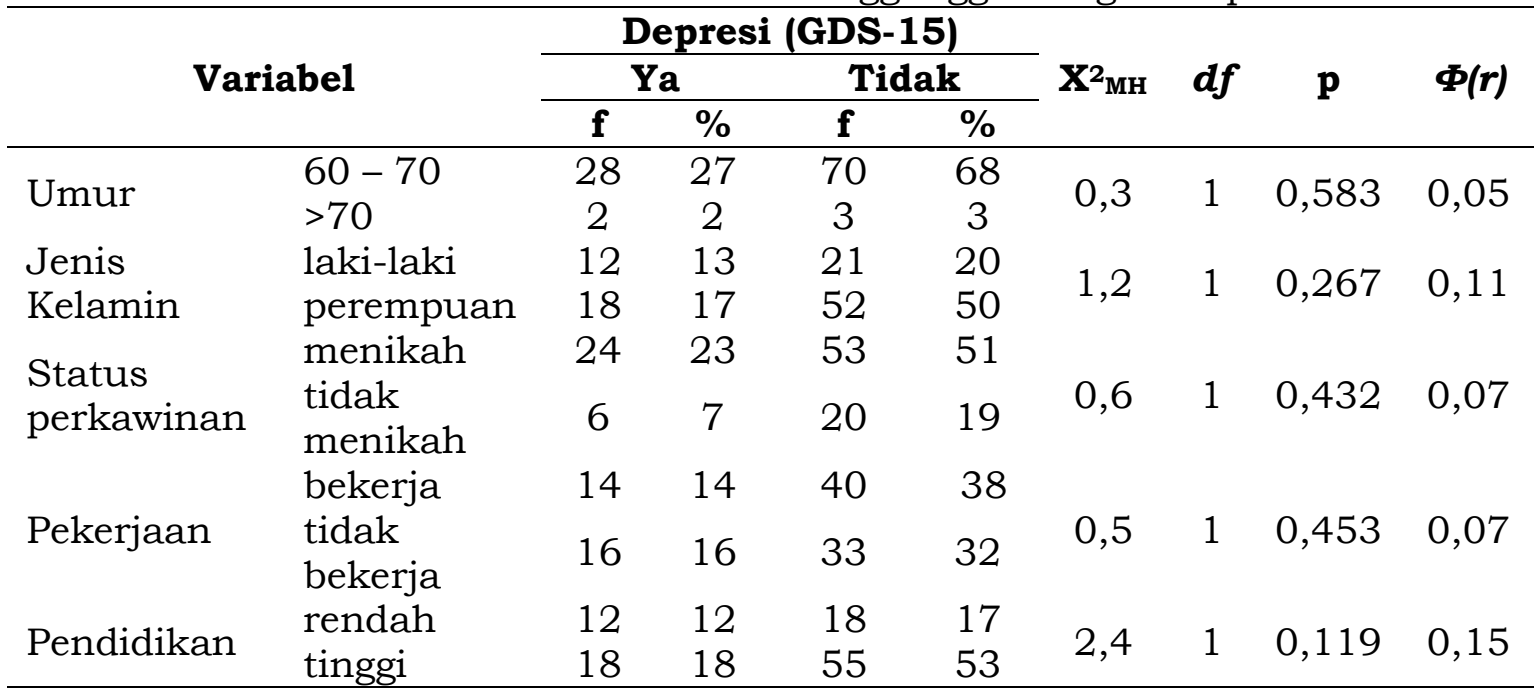

Sumber: Data primer penelitian

Variabel umur, jenis kelamin, status perkawinan, pekerjaan dan pendidikan menunjukkan tidak ada hubungan yang bermakna dengan kejadian depresi pada subyek penelitian $(p<0,05)$ yaitu berturutturut $p=0,583, p=0,267, p=0,43$, $\mathrm{p}=0,453$ dan $\mathrm{p}=0,119$. 


\section{Analisis Multivariat dengan Uji Regresi Logistik dan Multipel Regresi}

Berdasarkan hasil Analisis Bivariat antara variabel pengganggu terhadap depresi didapatkan tidak ada satupun yang mempunyai nilai $\mathrm{p}<0,25$ (syarat analisis Multivariat, maka analisis Multivariat dengan Uji Regresi Logistik tidak dapat dilakukan oleh karena tidak memenuhi persyaratan untuk analisis Multivariat. 19

\section{Pembahasan}

Subjek penelitian ini di dominasi oleh perempuan sebanyak 70 orang $(68 \%)$, sisanya oleh laki-laki sebanyak 33 orang (32\%). Dari keseluruhan subjek penelitian didapatkan yang depresi sebanyak 30 orang dimana yang terbanyak mengalami depresi yaitu subjek penelitian perempuan berjumlah 18 orang $(17 \%)$ dan laki-laki 12 orang $(12 \%)$. Sepuluh urutan keadaankeadaan yang dirasakan oleh subjek penelitian berdasarkan instrumen GDS-15 dari yang terbanyak sampai yang sedikit yaitu : (1) Merasa tidak berdaya sebanyak $11 \%$. (2) Masalah daya ingat sebanyak 10\%. (3) Merasa bosan sebanyak 9\%. (4) Takut sesuatu yang buruk akan terjadi sebanyak 9\%. (5) Lebih senang dirumah dari pada keluar mengerjakan hal yang baru sebanyak $8 \%$. (6) Meninggalkan banyak kegiatan dan minat sebanyak $8 \%$. (7) Menganggap orang lain lebih baik keadaannya sebanyak 7\%. (8) Merasa tidak berharga sebanyak 6\%. (9) Merasa kehidupan kosong sebanyak $6 \%$. (10) Hidup tidak menyenangkan sebanyak $6 \%$.

Berdasarkan instrumen MLQ ditemukan 10 urutan jawaban dari yang terbanyak dan terendah yaitu:

(1) Mempunyai perasaan yang baik untuk membuat hidup berarti sebanyak 12\%. (2) Memiliki tujuan hidup yang jelas sebanyak 12\%. (3)
Selalu mencari sesuatu yang dapat membuat hidup menjadi lebih baik sebanyak 11\%. (4) Mencari sesuatu yang dapat membuat hidup berarti sebanyak 10\%. (5) Memahami arti hidup sebanyak 10\%. (6) Selalu berusaha menemukan tujuan hidup sebanyak 10\%. (7) Tidak memiliki tujuan hidup yang jelas sebanyak 9\%. (8) Menemukan tujuan hidup yang dapat membuat puas sebanyak 9\%. (9) Mencari arti dalam hidup sebanyak 9\%. (10) Mencari tujuan hidup sebanyak $8 \%$.

Berdasarkan hasil instrumen Kebermaknaan Hidup ditemukan aitem pencapaian dalam kebermaknaan hidup lebih tinggi dibandingkan dengan aitem pencarian dalam makna hidup.

Pada penelitian dari 78 subjek penelitian didapatkan depresi sebanyak 21 orang $(27 \%)$ dengan jumlah terbanyak pada subjek perempuan sebesar 15 orang dan laki-laki 6 orang. ${ }^{20}$ Beberapa penelitian menunjukkan bahwa prevalensi depresi mayor sekitar 2$5 \%$ pada populasi umum. ${ }^{21}$ Perempuan lebih sering mengalami depresi dua kali dibandingkan lakilaki. ${ }^{22}$ Pada penelitian ini didapatkan hasil yang berbeda dimana perbandingan yang mengalami depresi antara perempuan dan lakilaki didapatkan 18:12.

Pada penelitian ini subjek penelitian didominasi lansia yang berusia 60-70 tahun sebanyak 98 orang $(95 \%)$, sementara sisanya usia $>70$ tahun sebanyak 5 orang (5\%). Hal ini menurut Ketua Posyandu Lansia Padukuhan Soropadan, Sleman, Yogyakarta dikarenakan lansia dengan usia $>70$ tahun sudah tidak kuat untuk datang ke posyandu. Subjek penelitian yang berusia 60-70 tahun mengalami depresi sebanyak 28 orang $(27 \%)$ dan yang berusia $>70$ tahun sebanyak 2 orang $(2 \%)$. 
Subjek penelitian yang bekerja terdapat 54 orang (52\%) dan tidak bekerja 49 orang (48\%). Pada subjek penelitian yang bekerja ditemukan 14 orang (14\%) mengalami depresi dan yang tidak bekerja ditemukan 16 orang (16\%) mengalami depresi. Hasil uji bivariat didapatkan tidak ada hubungan yang signifikan antara pekerjaan dan depresi, hal ini berbeda dengan yang penelitian yang dilakukan oleh Wong \& Almeida, (2013) bahwa status pekerjaan berhubungan depresi. Dimana lansia yang masih bekerja memiliki resiko terhadap depresi karena waktu mereka lebih banyak dihabiskan untuk bekerja diluar rumah setiap harinya sehingga waktu bagi lansia untuk berpartisipasi di dalam kegiatan sosial, berkumpul dengan keluarga dan rekreasipun menjadi ber-kurang. ${ }^{23}$

Subjek penelitian yang menikah pada penelitian ini yang mengalami depresi sebanyak 24 orang $(23 \%)$ sedangkan yang tidak menikah (janda/ duda) mengalami depresi sebanyak 6 orang $(7 \%)$. Hasil analisis bivariat didapatkan hubungan yang tidak signifikan dengan depresi, hal ini berbeda dengan menurut Kaplan \& Sadock's, (2007) salah satu faktor yang dapat menyebabkan terjadinya depresi adalah status perkawinan dimana orang yang tidak memiliki pasangan terutama perempuan atau berstatus janda lebih rentan terhadap depresi, sehingga seseorang yang kehilangan pasangan hidupnya maka berkurang pula dukungan keluarga terhadapnya. ${ }^{24}$ Dimana dukungan keluarga sangat penting bagi lansia karena kurangnya dukungan keluarga dapat mencetuskan depresi, seperti perasaan ditelantarkan atau tidak mendapat perhatian yang memadai dari keluarga. ${ }^{25}$ Menurut Gao et al., (2010) seseorang yang memiliki status perkawinan duda atau janda beresiko hidup sendiri dan merupakan faktor resiko terjadinya depresi pada lansia. ${ }^{26}$

Data pada tabel 4 menunjukkan bahwa lansia sebagian besar dengan tingkat pendidikan tinggi mengalami depresi sebanyak 18 orang (18\%) dan yang berpendidikan rendah mengalami depresi sebanyak 12 orang (12\%). Berdasarkan analisis bivariat didapatkan hubungan yang tidak signifikan antara pendidikan dengan depresi, hal ini sesuai dengan hasil penelitian yang mengatakan bahwa pola pendidikan dari golongan lanjut usia di Indonesia yang umumnya sekitar $71,2 \%$ belum mengenal pendidikan formal, sehingga lansia sudah bisa menyesuaikan diri sejak dahulu dengan tingkat pendidikannya sehingga tidak mempengaruhi keadaan mood, perasaan dan harapan hidupnya. ${ }^{25}$

Hal ini berbeda dengan penelitian yang dilakukan oleh Lièvre, Alley \& Crimmins, (2008) pendidikan yang rendah berkaitan dengan depresi terutama pada usia lanjut, hal ini karena orang-orang dengan pendidikan yang lebih rendah akan mencapai usia tua dengan penurunan kognitif dan kesehatan fisik yang buruk. Proporsi gangguan depresi pada usia 70 tahun atau lebih tua dengan tingkat pendidikan yang rendah adalah 11,5\% sedangkan mereka yang berpendidikan tinggi hanya $3,5 \%$. Hasil penelitian ini berbeda karena pada jurnal dijelaskan bahwa lansia dengan tingkat pendidikan yang rendah akan mempengaruhi fungsi kognitif, kesehatan fisik dan kualitas hidupnya. 25

Pada penelitian ini didapatkan subjek penelitian yang mempunyai tingkat kebermaknaan hidup yang tinggi sebanyak 97 orang (94\%) dan yang kebermaknaan hidupnya rendah sebanyak 6 orang $(6 \%)$. Dari 97 orang subjek penelitian yang mempunyai tingkat kebermaknaan 
tinggi didapatkan yang mengalami depresi sebanyak 25 orang (24\%) dan yang tidak depresi sebanyak 72 orang (70\%). Dari 6 subjek penelitian yang mempunyai tingkat kebermaknaan hidup yang rendah sebanyak 5 orang (5\%) mengalami depresi dan 1 orang tidak mengalami depresi (1\%).

Tingginya tingkat kebermaknaan hidup dan rendahnya depresi pada lansia di Posyandu Lansia Padukuhan Soropadan, Sleman, Yogyakarta hal ini sesuai dengan keterangan Ketua Posyandu Lansia dan para kader didapatkan bahwa para lansia yang ada di Padukuhan Soropadan hidup rukun dan damai, belum pernah muncul konflik di antara para lansia.

Terdapat korelasi terbalik antara kebermakanaan hidup dengan depresi pada lansia artinya semakin tinggi tingkat kebermakna-an hidup pada lansia maka semakin tidak ditemukan adanya depresi. Hasil penelitian ini tidak jauh berbeda dengan penelitian lainnya yaitu: penelitian pada populasi lansia di kota dan pedesaan Swedia bagian Utara yang menyebutkan 40 subjek penelitian $(21,2 \%)$ dari total 189 yang depresi memiliki skor kebermaknaan hidup yang rendah $(p=0,014) .{ }^{20}$ Pada penelitian didapatkan adanya hubungan yang signifikan antara depresi dengan penurunan tingkat kebermaknaan hidup pada penelitian cross-sectional tetapi pada penelitian prospektif, tidak ada perbedaan yang bermakna antara yang depresi dan tidak depresi dengan tingkat kebermaknaan hidup. ${ }^{20}$

Lansia yang memiliki makna hidup dapat melihat tujuan yang lebih besar dan saling keterkaitan dalam kehidupan, merasa lebih memegang kendali dalam mengarahkan hidupnya, serta menunjukkan keinginan kuat untuk mendapatkan kehidupan yang lebih baik. ${ }^{27}$ Mereka tidak mudah mengalami depresi dibandingkan dengan individu yang mementingkan diri sendiri, tanpa memiliki komitmen nyata untuk pengembangan pribadi, interpersonal, atau masyarakat. Memiliki makna hidup berarti dapat meningkatkan semangat hidup dan meletakkan dasar untuk kesejahteraan. Kehilangan makna hidup dapat menurunkan semangat untuk hidup, yang pada gilirannya dapat menyebabkan perasaan kekosongan dan depresi, dan dalam kasus terburuk, hingga bunuh diri. 27

\section{Keterbatasan Penelitian}

Terdapat beberapa variabel yang tidak diukur dalam penelitian ini seperti fungsi kognitif, gangguan jiwa sebelumnya, faktor penyakit kronis dan faktor-faktor yang berhubungan dengan depresi serta variabel lain yang belum tercakup dalam tinjauan pustaka.

\section{KESIMPULAN}

Terdapat korelasi yang bermakna antara tingkat kebermaknaan hidup dengan depresi pada lansia di Posyandu Lansia Padukuhan Soropadan, Sleman, Yogyakarta.

\section{DAFTAR PUSTAKA}

1. Infodatin Pusat Data dan Informasi Kementerian Kesehatan RI. Situasi Lanjut Usia (Lansia) di Indonesia. Report. 2016;8.

2. CIA World Factbook. Sepuluh Negara dengan Jumlah Penduduk Terbanyak di Dunia. https:// www.cia.gov/library/publication s/the-world-factbook/geos/id. html. 2016.

3. United Nations. World Population Ageing 2013. http://www. un.org/en/development/desa/po pulation/publications/pdf/agein g/WorldPopulationAgeing2013.p df. 2013.

4. Sumarni. Pengaruh permainan humor, kearifan budaya local, dan 
dukungan spiritual terhadap depresi pada lanjut usia di Hunian Sementara Gondang dan Kuwang Kabupaten Sleman. Transcult Psychiatry J (Belum di Publ. 2012;

5. World Federation for Mental Health. Depression: A Global Crisis. World Fedaration Ment Heal. 2012;1-32.

6. Marchira CR, Wirasto RT, Sumarni. Pengaruh Faktor-Faktor Psikososial Dan Insomnia Terhadap Depresi Pada Lansia Di Kota Yogyakarta. Ber Kedokt Masy. 2007;23(1):1-5.

7. Kementerian Kesehatan RI. Kesehatan Dalam Kerangka Sustainable Development Goals (SDGs). 2015;

8. Bastaman. Logoterapi: psikologi untuk menemukan makna hidup dan meraih hidup bermakna. Raja Grafindo Persada; 2007.

9. Kállay É. The investigation of the relationship between the meaning attributed to life and work, depression, and subjective and psychological well-being in Transylvanian Hungarian young adults. Cogn Brain, Behav. 2015;19(1):17-33.

10. Sharer N. Examining Social Anxiety and Depression Among Excessive Online Gamers. 2012;

11. Sastroasmoro S, Ismael S. Dasardasar Metodologi Penelitian Klinis. 3rd ed. Sagung Seto; 2010.

12. Steger MF, Frazier P, Oishi S, Kaler M. The Meaning in Life Questionnaire: Assessing the presence of and search for meaning in life. J Couns Psychol. 2006;53:80-93.

13. Alim S. Pengaruh Religiusitas Terhadap Kebermaknaan Hidup Narapidana di Lembaga Permasyarakatan Wanita Kelas II A Malang. Skripsi. Universitas Islam Negeri (UIN) Maulana Malik Ibrahim, Malang; 2012.
14. Nauli FA. Pengaruh Logoterapi Lansia dan Psikoedukasi Keluarga Terhadap Depresi dan Kemampuan Memaknai Hidup Pada Lansia di Kelurahan Katulampa Bogor Timur. Fak Ilmu Keperawatan Progr Magister Ilmu Keperawatan, Univ Indones. 2011 ;

15. Sarfika R. Pengaruh Terapi Kognitif dan Logoterapi Terhadap Depresi, Ansietas, Kemampuan Mengubah Pikiran Negatif, dan Kemampuan Memaknai Hidup Klien Diabetes Melitus di RSUP Dr.M.Djamil Padang [Internet]. Universitas Indonesia; 2012. Available from: lib.ui.ac.id/ file?file $=$ digital $/ 20351536-\mathrm{PR}-$ Ade Lisna.pd

16. Saliyo. Intensitas Zikir, Religiusitas, Makna hidup dengan Subjective Well Being Santri Spiritual Tarekat Naqsabandiyah Kholidiyah. Disertasi,progr Dr Psikol Fak Psikol Univ Gadjah Mada. 2015;

17. Purnomo S. Koefisien Korelasi Cramer dan Koefisien Korelasi Phi Serta Penerapannya. Universitas Negeri Yogyakarta; 2014.

18. Dahlan S. Penelitian Diagnostik. Jakarta: Salemba Medika; 2009.

19. Dahlan MS. Statistik Untuk Kedokteran dan Kesehatan. Jakarta: Salemba Medika; 2011.

20. Hedberg P, Gustafson Y, Aléx L, Brulin C. Depression in relation to purpose in life among a very old population: A five-year follow-up study. Aging Ment Health. 2010;14(6):757-63.

21. Dunn $\mathrm{N}$, Inskip $H$, Kendrick $T$, Oestmann A, Barnett J, Godfrey $\mathrm{K}$, et al. Does perceived financial strain predict depression among young women? Longitudinal findings from the Southampton women's survey. Ment Health Fam Med. 2008;5(1):15-21.

22. Kessler RC, Berglund P, Demler $\mathrm{O}$, Jin R, Merikangas KR, Walters 
EE. Lifetime Prevalence and Ageof-Onset Distributions of. Arch Gen Psychiatry 2005;62(June):593-602.

[Internet].

Available from: http://archpsyc. jamanetwork.com/article.aspx?d oi $=10.1001 /$ archpsyc.62.6.593

23. Wong JD, Almeida DM. The effects of employment status and daily stressors on time spent on daily household chores in middleaged and older adults. Gerontologist. 2013;53(1):81-91.

24. Kaplan \& Sadock's. Synopsis of Psychiatry Behavioral Sciences/ Clinical Psychiatry. 10th ed.
Philadelphia: Lippincott Williams \& Wilkins; 2007.

25. Kurniasari ND. Faktor - Faktor Yang Berhubungan Dengan Depresi Pada Lansia di Dusun Kalimanjung Ambarketawang Gamping Sleman Yogyakarta. 2014;

26. Gao S, Jin Y, Unverzagt FW, Liang C, Hall KS, Ma F, et al. Correlates of depressive symptoms in rural elderly

Chinese. 2010;24(12):1358-66.

27. Suprapto HUH. Konseling logoterapi untuk meningkatkan kebermaknaan hidup lansia. 2013;I(2):190-8. 